\title{
Orthodox Christian rigorism: attempting to delineate a multifaceted phenomenon
}

\author{
Vasilios N. Makrides
}

In the historically Orthodox Christian heartlands of Eastern and South Eastern Europe, as well as sometimes in the Orthodox diasporic communities around the globe, one may come across fundamentalist-like phenomena. For various reasons explained in this paper I subsume these cases under a category which I call rigorism. Such cases exhibit certain particularities vis-à-vis their Western Christian or Islamic counterparts and also attest to the diversity existing within the wider and dispersed body of Orthodox Christianity. Orthodox rigorists of varied provenance are at times in serious tension and conflict with the respective official Orthodox Churches, while in other instances they collaborate with them for common purposes. Using various theoretical perspectives on this topic and selected examples from different Orthodox contexts, this paper attempts to delineate the main contours of this phenomenon by focusing on the bearers of rigorism and their activities, the main characteristics, the socio-historical background and the later transformations of this phenomenon including its endogenous and exogenous causes. Finally, the potential resources and counter-currents from within the Orthodox world, which are aimed at neutralizing the rigorist influences, are also presented and discussed.

Vasilios N. Makrides is Professor of Religious Studies (specializing in Orthodox Christianity) at the Faculty of Philosophy of the University of Erfurt, Germany.

\section{Introduction}

Talking about fundamentalism nowadays is neither unusual nor occasions any surprise, for the term is widely and even increasingly used in the scholarly world and beyond it with reference to many and quite diverse contexts, religious and non-religious alike. Having originally been coined by external observers as a term of opprobrium to describe a conservative surge among American Protestants opposing liberal trends in the USA in the early $20^{\text {th }}$ century, the use of this term was later significantly amplified. It thus came to describe numerous groups in other religions (e.g. Islam), without losing its original significance and connotation. The later growing politicization of fundamentalist movements and their efforts to gain firm footholds in society were also thematized in this context. Nonetheless, the term has often been criticized as being too generic and allencompassing, hence lacking analytical abilities, precision and usefulness. ${ }^{1}$ This is

1 See Antes 2000. 
because many related phenomena are lumped together as fundamentalist, a fact obscuring or neglecting their potential idiosyncrasies and differences. It is true, though, that this term has been long established in scholarly and non-scholarly usage, thus it will make little sense to try to drop it or replace it by another, more pertinent one. As is well-known, terminological issues are quite hard to deal with. Suggesting a new term as an alternative to fundamentalism (e.g. radicalism, extremism) will not automatically solve the related problems and may even contribute to more confusion and misunderstandings than before.

Therefore, it has been conclusively argued that it is better to try to clarify the already widely used and established term through a more adequate typology or otherwise. ${ }^{2}$ This has been attempted in recent decades as a way to overcome previous difficulties with this term, although the categories and the criteria used for this purpose vary significantly. For example, Martin Riesebrodt argued for a necessary distinction between fundamentalism and traditionalism, first because fundamentalism may include new elements as being the result of a transformational process, and second because it constitutes a militant, mobilized traditionalism. To this purpose, he referred to Karl Mannheim's model of transition from traditionalism to conservatism. ${ }^{3}$ In addition, other general questions regarding this phenomenon need further reflection and, if possible, clarification: does fundamentalism simply reflect a particular individual attitude, or is it embedded in a specific social milieu and concomitant movement? What are the differences between fundamentalist and other protest movements? Is there a fundamentalism avant la lettre? Should fundamentalism be viewed solely as a threat and a grave danger? Should the term be applied solely to religious phenomena or more broadly to the non-religious domain? What are the relations between fundamentalism and modernity as a whole ? $^{4}$

Another issue worth discussing in the present context is the existence of some terms parallel to fundamentalism that have also been in use and that also contribute to the above terminological complications. Perhaps the most prominent of these terms is integrism, which has also been used to describe certain fundamentalist-like phenomena. This is especially the case in the related French or Italian literature (intégrismelintégralisme or integrismo/integralismo). Characteristically enough, while the term "fundamentalism" was more commonly used for the Protestant case, the term "integrism" was mostly used with regard to related phenomena within Roman Catholicism, whereas both terms have also been used with regard to Islam. This signifies that certain differences may be located between the various Christian traditions with regard to such phenomena, despite some undeniable commonalities. ${ }^{5}$ These and other particularities and

2 See Riesebrodt 1990, p. 18.

3 See ibid., pp. 215-216.

4 See Makrides 1994a.

5 See Alexander 1985. 
difficulties become more apparent when one tries to translate the above terms into foreign languages and convey their meaning in an adequate way. ${ }^{6}$

Now turning my attention to the Orthodox Christian world, which is the main focus of the present article, it should be acknowledged that we also find phenomena here which fall under the range of significance of the above terms and in most cases are characterized as, or called, fundamentalist. In various texts of mine, written in different languages, both the term "fundamentalism", as well as the term "integrism" " have been used to describe and analyze related phenomena. Other scholars dealing with Orthodox Christianity have also done the same, yet from different standpoints and perspectives. ${ }^{9}$ In fact, several of the general characteristics of such movements (Protestant and otherwise) appear to be found mutatis mutandis among their Orthodox counterparts. However, in the scholarly literature on these phenomena the Orthodox Christian case has generally not been taken into account. For example, in the ambitious, five-volume The Fundamentalism Project (1991-1995) of the American Academy of Arts and Sciences, coordinated by Martin E. Marty and R. Scott Appleby, the related Orthodox phenomena are conspicuously absent.

Yet, from a later perspective and taking into consideration the numerous specificities and particularities of the Orthodox Christian context, my preference lies with using a more neutral term to talk about such phenomena. Similar caveats have also been expressed with regard to the other terms mentioned above. For instance, although there have been interesting attempts to transform terms like fundamentalism into sociological categories with potentially universal applicability as indicating a very specific form of religious revival, ${ }^{10}$ its application as an appropriate term to designate and describe specific phenomena within Roman Catholicism has been questioned. ${ }^{11}$ Furthermore, we should seriously consider the fact that, generally speaking, there is a scarcity of stricto sensu fundamentalist movements in Europe vis-à-vis the USA or the rest of the world. ${ }^{12}$ This has been attributed to many causes; for example, to the influence of the Enlightenment upon Christianity in Europe. This lack of fundamentalism is also considered as a feature underlining Europe's exceptionalism regarding its own particular religious evolution. ${ }^{13}$ However, the above observations are grounded more in the

6 Regarding the related Greek case, see Makrides 1994b.

7 See Makrides 1991 and 2000.

8 See Makrides 2003, pp. 215-221.

9 Concerning the term "fundamentalism", see Morris 1998; Uliakhin 2003; Hovorun 2016; concerning the term "integrism", see Yannaras 1990, p. 31; Lossky 1992; Kitsikis 1994.

10 See Riesebrodt 2000, pp. 269-271.

11 See Casanova 1994.

12 See Davie 2002, p. 24.

13 See Davie 2000a, p. 460. 
religious history of Western Europe. If we take a look at Orthodox Eastern and South Eastern Europe, we do realize the existence of numerous protest groups and movements exhibiting significant similarities to American Protestant and Islamic fundamentalism, as well as to Roman Catholic integrism.

Nevertheless, since we are dealing with the very specific Orthodox religious and cultural milieu, it would be more adequate to describe the phenomena under consideration with another term. It is for this reason that I have opted for the term "rigorism"14, which is again not unknown in the related ample literature, despite its rather limited use. ${ }^{15}$ Eschewing an essentialist definition of this term, it is, first, a more inclusive one covering various phenomena with family resemblances. More importantly, it may also include phenomena that historically precede the first appearance of the term "fundamentalism". In fact, this is what particularly applies to the Orthodox case. Second, it allows the flexible use of elements from various theoretical schemes in order to do justice to the particularities of the given case. Third, it is more neutral, since other terms have quite a loaded history, having been associated in the past with a specific religion or culture, a fact that often obscures their analytical usefulness. Hence, its use with regard to Orthodox Christianity is principally unproblematic. Fourth, it underlines some main features of such phenomena; namely the uncompromising positions, the intransigence, the radicalness and the militancy of certain hardliners in upholding their own views, often being antagonistic towards the surrounding culture and the leadership of their religion. For all these reasons, this term seems to be more appropriate and fitting to the Orthodox situation, where the cleavage between the church hierarchy and the rigorists is usually evident.

To be more specific, for various reasons it is inadequate to simply place the Russian Old Believers (from the late $17^{\text {th }}$ century onwards) or the various groups of Old Calendarists (from the early $20^{\text {th }}$ century onwards) in different contexts both having to do with a strong attachment to ritualism and established liturgical traditions - under the category of fundamentalism. The first case especially has a much longer history than the term "fundamentalism" and modern related phenomena. Moreover, this term fails to bring to light some common and key features of these Orthodox protest movements; for example, their strong anti-Western stance, as well as their care for and rigor in interpreting and upholding the highly treasured Orthodoxy as the sole right faith in the entire world. A similar problem may be detected when referring to Scripturalism (a strict adherence to a literal interpretation of the Bible), which can be observed both among Orthodox rigorists and Protestant fundamentalists. Apparently, both cases share many common characteristics in this regard, yet the differences between them are again conspicuous and cannot be made clear if we were to talk indistinctly of a "Biblical

14 See Makrides 2004 and 2014a.

15 See Gellner 1992, p. 2; Gladigow 1993; Harwazinski 1999. 
fundamentalism"16. Orthodox Scripturalism has again a much longer history than the Protestant one and is further connected with several other key issues (e.g. the role of tradition), which are lacking in the Protestant counterpart. By introducing the term "rigorism" thus, my intention is neither to solve the aforementioned terminological problems, nor to propose it as the ideal one to be used generally in related contexts. It is basically about a more neutral and appropriate term, which can be applied to various cases including the Orthodox one and conceptualized accordingly.

\section{Who are the Orthodox rigorists?}

The bearers of Orthodox rigorism do not represent a single and uniform unit, but can be located across a wide spectrum of people with varied provenance, social status and orientation. These may act individually and independently in specific contexts, but in other cases they may be organized in respective movements, organizations and groups, thus enhancing their mobilization power, visibility and effectiveness. The main problem, however, is that they cannot be always identified as such, for they may also appear and act in broader settings that include other groups and actors, as well, and sometimes non-religious ones. The chief issue here is to locate the differentiae specificae of Orthodox rigorism. For instance, to express anti-modern views or exhibit an anti-Western stance neither renders someone nor a group automatically rigorist.

This holds, at first, true for the church hierarchy and selected members of it who may profess such views or may entertain close relations with rigorists. In most cases, such rigorists can be distinguished from the official church hierarchy and the mainstream Orthodox believers. However, no absolute and strict demarcation line can be drawn between them, as the boundaries remain in many cases fluid and easily penetrable. The phenomenon of church hierarchs supporting rigorists out of various considerations and for numerous reasons is not out of the ordinary. The church hierarchies in predominantly Orthodox countries, mostly in Eastern and South Eastern Europe, try to keep a balanced and diplomatic position in society, not least because of their close relations with the respective states. Yet, the phenomenon of some bishops expressing extreme views and having close contacts with or even supporting Orthodox rigorists is not unusual. Despite attempts to silence or isolate them, they always manage to voice their highly critical views and make headlines.

The Greek Metropolitan of Florina, Eordaia and Prespes Augustinos Kantiotis (1907-2010, in office between 1967 and 2000), was notorious in this respect and has left quite a vivid legacy among his numerous followers through his religious

See Makrides 1995, pp. 568-625. 


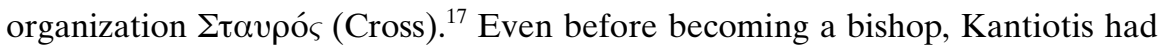
been known throughout Greece as a militant and uncompromising person. $\mathrm{He}$ had frequent conflicts with his church colleagues, who did not share his militancy while trying to isolate him. "Kantiotism" has therefore been considered by many as a scourge within Greek Orthodoxy. ${ }^{18}$ It is noteworthy that the Patriarchate of Constantinople intervened in cases when Kantiotis' followers were accused of rigorist and subversive activities in various Orthodox dioceses, such as in Australia. A lay theologian of Kantiotis' movement, Nikolaos Sotiropoulos, was formally excommunicated by the Patriarchate in 1993 on the grounds of such activities. ${ }^{19}$ Yet, the very fact that Kantiotis remained simultaneously a member of the church hierarchy and a major representative of rigorism reveals the complexity of their intertwined connections and the dynamics that can develop in this context. Currently, the Greek Metropolitan of Piraeus, Serapheim (Mentzelopoulos), is another member of the church hierarchy representing such a rigorist stance. His controversial positions on many issues (e.g. anti-Semitic, anti-modern, anti-Ecumenical, anti-Catholic) have stirred many reactions from different sides including from other Orthodox hierarchs. ${ }^{20}$ Within the Russian Orthodox Church one can also locate several bishops with a similar rigorist mentality, reacting against their more liberal or moderate fellows. ${ }^{21}$ Consequently, the Metropolitan of St. Petersburg and Ladoga Ioann Snychev (1927-1995) has been placed in this category. ${ }^{22}$

Such cases are generally isolated and do not represent those of the Orthodox mainstream and that of the church hierarchy as a whole trying to mitigate in debatable issues and keep a more balanced and reasonable stance. Yet, the church position as such is not absolutely clear on this matter and remains rather ambivalent. On the one hand, it avoids being associated with rigorism, but on the other hand, it makes use of the rigorist potential to strengthen its own initiatives, policies and strategies under specific circumstances. Whenever there was a major conflict between church and state, the former usually mobilized the entire Orthodox flock without making any distinctions. In this sense, Orthodox rigorists are equally eager to support the official church in such critical moments, because their final aim is not its dissolution, but its amelioration. For example, Greek Orthodox rigorists of every provenance played a crucial role in the massive demonstrations against the socialist government's plans to nationalize the ecclesiastical and

17 See Giannakopoulos 1999, pp. 327-332.

18 See Stylianos 1994, p. 576.

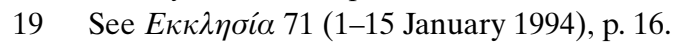

20 See Seraphim (Mentzelopoulos) of Piraeus on orthodoxwiki, available at: http:// orthodoxwiki.org/Seraphim_\%28Mentzelopoulos\%29_of_Piraeus [24.01.2016].

21 See Mitrokhin 2004, pp. 185-190.

22 See Slater 2000; Shnirelman 2015, p. 137. 
monastic property in $1987,{ }^{23}$ as well as against another state decision to drop the data on religious affiliation from new identity cards in $2000^{24}$. In various incidents (1994-1995) related to the exclusive religious or secular use of an old historic Roman building in the city of Thessaloniki in Greece, the Rotunda, the local diocese mobilized many rigorists, who were considered responsible for some riots, clashes and violent actions that occurred there. ${ }^{25}$ Understandably, all this complicates again the separation between official church hierarchy and rigorists. It should also be mentioned that in such broader mobilization attempts, other and especially non-religious actors may participate, such as those stemming from the right or even extreme right political spectrum. For example, the recent rise of such a political party named "Golden Dawn" in Greece has revealed that it has many sympathizers from the broader Orthodox domain, although there is also an Orthodox criticism against it, especially against its fascist and neo-pagan leanings. ${ }^{26}$

The above ambivalence becomes evident also by considering that the rigorists do not intend to leave Orthodoxy for another religion, but they basically criticize the present condition of the church as unacceptable. In most cases, they would have preferred to submit themselves to the church hierarchy provided that it had fulfilled their needs and visions completely. Even in cases when there is a schism between rigorists and the official church, the ideal solution for both sides is reunification, although the requirements for such an undertaking are seen differently by each side. Therefore, the harsh critique of the official church by the rigorists should not obfuscate the fact that they both have much more in common than simply differences.

This applies first to the Old Calendarists. Although separated administratively from the official church, moderate Old Calendarist circles still acknowledge its legitimacy and recognize the sacraments it performs, only opposing its innovations and Ecumenical compromises. Solely Old Calendarist hardliners follow the austere line of a complete separation, claiming that the official (New Calendarist) church has completely lost the sanctifying grace of sacraments and fallen victim to apostasy and heresy. ${ }^{27}$ Mainstream Orthodox believers are not prohibited by the official church from going to Old Calendarist churches, a fact showing the fluidity of the above separation markers. The same is true for the monastic community of the Holy Mountain Athos. Although it follows the old calendar, it shows no discrimination, aside from the Zealots, towards the New Calendarist Orthodox believers and keeps good relations with the church hierarchy and the state. After all, there are no major dogmatic and other differences

\footnotetext{
23 See Dépret 2010.

24 See Makrides 2005; Dépret 2012.

25 See Stewart 1998.

26 See Sakellariou 2014.

27 Brady and Melling (2001, p. 356), who distinguish here between "resistance" and "integrist" Old Calendarism.
} 
between the Old Calendarists and the mainstream Orthodox Church, aside from the calendar issue.

Yet, occasional cooperation between the official church and rigorists does not signify the normalization of their relations. The official church is aware of the potential danger that rigorists may bring to the unity of the church body, thus it intends to keep them completely under control and to mitigate their militancy, while also mobilizing them for common objectives. This policy is however not very successful, especially when rigorist criticism of the official church escalates into real confrontation. The radical and violent events in the early 1990s in the diocese of Larissa and Tyrnavos in Greece proved that the rigorist camp cannot be kept under control or used ad libitum according to the will of the church hierarchy. ${ }^{28}$ The seriousness of this prolonged conflict forced the then Archbishop of Athens and All Greece Serapheim (Tikas) to issue official encyclicals condemning the rigorist positions and actions as non-Orthodox and admonishing the mainstream Orthodox flock to keep a distance from them. ${ }^{29}$ In many cases, rigorists are thus seen as a real threat, and harsh measures against them on the part of the official church are not out of the ordinary.

Another example may illustrate this situation. In December 2002 the Patriarch of Constantinople Bartholomew I declared the Zealots of the Esphigmenou Monastery of the Holy Mountain Athos schismatic and outside the church, and tried to expel them until the end of January 2003 with the help of state authorities. His intention was to bring this monastery into full communion with the rest of the Holy Community of Mount Athos. The main reason was that the Esphigmenou monks had been very critical of the Ecumenical endeavors of Patriarch Athenagoras (1886-1972) and his "dialogue of love" with the Roman Catholic Church from the 1960s onwards. Taking control of the monastery in 1971, they thus ceased commemorating the Patriarch's name in Liturgy and followed a strict and isolationist policy, refusing participation in the common administration of the Holy Community of Mount Athos. In the wake of the above decision, police authorities cut the electricity to the monastery and prevented the supply of food, heating oil and medical provisions, while more than 100 monks barricaded themselves in the monastery and appealed to the Council of State. The conflict still remains unsolved, ${ }^{30}$ while it attests to the strength, persistence and endurance of Orthodox rigorism. Aside from the Esphigmenou Monastery, there exist many other sim-

28 For the rigorist positions, see agonas-homepage, available at: http://www.agonas. org/ [24.01.2016].

29 See the encyclical no. 2564 of 25 October 1993 against the "Panhellenic Orthodox

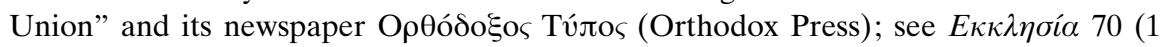
November 1993), p. 597.

30 See homepage of Esphigmenou Monastery, available at: http://www.esphigmenou. $\mathrm{com} /[24.01 .2016]$. 
ilarly-minded Zealot monks living as isolated hermits in the southern part of the Mount Athos peninsula. ${ }^{31}$

From the rigorist point of view, the main issues of controversy with the official church can be summarized as follows; first, the dependence of the church to the state, its rather superficial role in society, and all the concomitant compromises jeopardizing the authentic Orthodox tradition; second, the creation of a really free and living church organization through purification from all deficits, namely from moral and financial scandals to the modernizing and secularizing trends of many church hierarchs; third, the active participation of Orthodox lay believers in the election of their church leaders, who have to be blameless in every respect; fourth, the adulterating consequences of the contemporary global environment, including the European Union, on the preservation of the Orthodox tradition; and finally, the official participation of the Orthodox Church in the "heretical" Ecumenical Movement and the bilateral dialogues with other Christians, such as with Roman Catholics, who are considered to have deviated from the right faith. These issues are, however, raised occasionally by members of the official church, for they constitute matters of serious reflection (cf. the reaction of the aforementioned Metropolitan of Piraeus Serapheim against the visit of Pope Francis to the Greek island of Lesvos in April 2016 due to the refugee and migrant crisis $^{32}$ ). Likewise, anti-Ecumenical stances at the official church level are not an exception today. To be more specific, the Orthodox Church of Georgia in $1997^{33}$ and that of Bulgaria in $1998^{34}$ have formally withdrawn their membership from the World Council of Churches and the Conference of European Churches.

It is vital in this context to avoid confusing the rigorist positions of certain church hierarchs with the overall traditionalist stance of the church hierarchy. In fact, the church usually looks for a "third way" between rigorist and liberal positions and tries to mediate between the different camps. On the other hand, its general stance is admittedly more conservative, which brings it closer to the rigorist camp and explains their usual correlations and constant interferences. Being part of a long historical chain of fidelity to the bequeathed Christian tradition, the Orthodox Church is particularly sensitive to this issue. It also appears to be much more traditional than the Western Christian Churches, both Roman Catholic and Protestant. As a result, it often supports positions that are difficult to understand by Western criteria and modes of thinking.

According to several scholars, the above is the case with the official Russian Orthodox Church in post-Soviet times, exemplifying this "third way" between

\footnotetext{
31 See Brady 2001, p. 528.

32 See online article "Pura tou mitropoliti serafeim kata patriarhi kai papa", available at: http://www.protothema.gr/greece/article/568020/pura-tou-mitropoliti-serafeim-katapatriarhi-kai-papa-/ [15.04.2016].
}

33 See Crego 2014, pp. 146-147.

34 See Kalkandjieva 2014, p. 123. 
rigorism and liberalism. ${ }^{35}$ Its positions appear in many respects incompatible with those of the Western Churches and with the values of the Western world - consider, for example, its official position of 2008 on human dignity, freedom and rights, which has created many debates internationally. One of the main aims of this church today is the defense of so-called "traditional values", an agenda which has a clear anti-Western purpose. Despite all this, the same church does not retreat to its own insulated enclave, but seeks the dialogue with the Western Churches and the secular world while trying to develop its international and transnational activities in an impressive way. It would be thus amiss to call this church rigorist simply because of its critique of modern liberal secular values and orientations. Quite clearly, it does not share the militancy, the aggressiveness and the apocalyptic fervor usually characterizing the Orthodox rigorists. In addition, it always tries to keep the latter under control, as it fears an eventual intensification of rigorist reactions and their potential greater influence on the wider church body.

The same applied to the Orthodox Church of Greece under the leadership of the charismatic, yet controversial Archbishop Christodoulos (1998-2008). He was often accused of disseminating extreme and radical views, but his aim was to reverse the moderate secularization process within Greek society and to act against the privatization of religion by rendering the church a key public factor in the country. In this respect, despite similarities, his attitude was not clearly rigorist, but rather conservative and neo-traditionalist. ${ }^{36}$ Here it is about fine distinctions that draw necessary separation lines between the various phenomena under consideration in order to better capture their eventual specific characteristics and manifestations.

Furthermore, not every actor or group expressing anti-modern or anti-Western views can be subsumed under the category of Orthodox rigorism. In specific cases, certain movements lie somehow in-between sharing selected elements with rigorists, and distinguishing themselves from them on other issues. The semimonastic brotherhoods in $20^{\text {th }}$ century Greece, especially the one named Zw⿰ (Life), together with their affiliated sisterhoods and other dependent organizations, belong to this category. Basically, they were pietistic in outlook and focused more on internal mission and the spiritual improvement of their members. They also contributed to the spread of rigorism, especially through social activism, puritan ethics, patriarchal values, nationalistic orientations and antiWestern attitudes. Yet, these rigorist impulses were mitigated by their more balanced strategy towards the official church and society, usually avoiding getting involved in open conflicts. As a result, despite occasional distancing from, and tension with, the official church, there was never a schism between them ${ }^{37}$ Other movements, though, like the elitist intellectual one in Greece in the 1980s known

35 See Selbach 2002, pp. 152-165; Papkova 2011; Stoeckl 2014.

36 See Makrides 2014b, pp. 187-195.

37 See Giannakopoulos 1999; Dimanopoulou 2010. 
as "Neo-Orthodoxy", by no means belong to the category of rigorism. Aside from its intense anti-Westernism, the latter movement did not share many of the main rigorist characteristics and had other objectives. Other organizations, however,

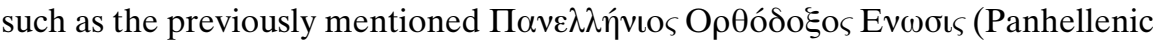
Orthodox Union), clearly belong to the rigorist camp, as they formulate a highly critical and aggressive discourse and seek to mobilize their adherents against anything that they perceive as danger for Orthodoxy and Greece.

What is then quite typical of Orthodox rigorist groups and actors? We should keep in mind that the rigorist camp is basically construed along cultural commonalities rather than class cleavages. ${ }^{38}$ Such rigorists usually exhibit a strong Manichaean mentality and are guided by apocalyptic and eschatological scenarios, based on the Book of Revelation and other prophetic texts and legends, about a general battle between good and evil and the imminent end of the world. Among them the enemy syndrome is particularly strong and pervasive. They constantly locate lurking enemies everywhere who have designs against Orthodoxy. This condition is further strengthened by conspiracy theories of all sorts (especially involving Jews and Freemasons) aimed at destroying the pristine Orthodox faith. Yet, we should not assume that rigorists are generally uneducated and ignorant persons, as a common and widespread stereotype about such and related people usually postulates. To put it correctly, it is about the overall rigorist discourse which lacks sophistication, complexity and erudition, as it tends to give simplistic, one-dimensional and categorical answers to the questions it deals with on the basis of a dichotomic logic. Additionally, rigorists place particular emphasis on the supposedly intact preservation of Orthodoxy, the sole true faith revealed by God in the entire world, and are ready to go to extremes in guarding and protecting it. They also defend puritanical ethics and patriarchal family values. As a result, they are usually militant in outlook and may also resort to violent actions in pursuing their goals, given that violence receives strong divine legitimacy by their overarching conceptual scheme. Another feature relates to the phenomenon of "Hyper-Orthodoxy", namely when rigorists accuse each other of betrayal and deviation from the right Orthodox path. This, in turn, leads to numerous internal schisms within the rigorist camp and to the creation of opposite splinter-groups competing and claiming the sole authentic possession of the right faith. ${ }^{39}$ In some extreme cases, rigorists may decide to sacrifice their lives for their beliefs in an apocalyptic battle against the "powers of darkness" and look for salvation in escaping this world. The sense of their electedness as representing the faithful remnant in a sinful world is particularly strong and pervasive among them and leads to greater tension with their surrounding environment, religious and otherwise. In general, the lines separating the rigorists from the outside fallen world (which may also include the official church) are drawn in strict and clear terms.

38 See Riesebrodt 2000, pp. 277-279.

39 See Makrides 1991, pp. 62-65. 
Such attitudes can be clearly observed in the early history of the Old Believers' movement in the Russian Empire, who separated themselves from the official church in 1666/7 after the church and ritual reforms initiated by Patriarch Nikon. These were interpreted as cardinal deviations from the already definitely established Orthodox faith and tradition, and as clear signs of the imminent coming of the Antichrist and the final battle between good and evil. As a result, they were violently persecuted afterwards by state forces with church support and retreated to isolated places in their own enclaves. In several cases at the end of the $17^{\text {th }}$ and early $18^{\text {th }}$ century, they preferred self-immolation in an utterly apocalyptic climate rather than surrendering to the state forces and the "heretical Russian Church", representing the fall from the right faith. In fact, these are believed to be the biggest mass suicide cases known in history. ${ }^{40}$ All this forced Old Believers to massive emigration abroad, and their communities are nowadays found in different parts of the world, from Central Asia to Canada and South America. From the $19^{\text {th }}$ century onwards they progressively gained more legitimacy in society, yet the typical features of Orthodox rigorism accompanied them constantly. Further, there were numerous internal schisms within the Old Believers' movement out of various reasons leading to the formation of many competing groups. Two wide sets of groups are those of the popovtsy (priestly) and the bezpopovtsy (priestless), having to do with the problem of legitimate priestly succession and the issue of authority in their ranks. ${ }^{41}$ Characteristically, the above mentioned features of a rigorist mentality can be observed among various contemporary Old Believers' communities across the globe, as a social anthropological study of such a community in Canada has vividly shown. ${ }^{42}$

Similar attitudes can be observed in the aforementioned protest movement of the Old Calendarists, the self-named "True Orthodox Christians", and their affiliated organizations. These came into being in the wake of the adoption of the new (corrected Gregorian) calendar by the Patriarchate of Constantinople in 1923 and by the Greek Orthodox Church in 1924. After initial (organized) opposition to the reform, a schism followed when three metropolitans left the Orthodox Church of Greece in 1935 and founded a separate synod. In particular, Old Calendarists condemned the Ecumenical openings of the Orthodox Church, especially of the Patriarchate of Constantinople, towards Western Churches and have always kept a highly anti-Ecumenical stance. But soon afterwards there were several internal splits within the Old Calendarist movement itself. This led to the creation of various jurisdictions of Old Calendarists in different countries, whose number is estimated in hundreds of thousands, while their sympathizers are much more numerous. Today, Old Calendarists are found not only in Greece, Cyprus, Romania and Bulgaria, but also have communities and deploy activities else-

40 See Robbins 1986.

41 See Feldmann 1995.

42 See Scheffel 1991. 
where (Western Europe, USA). There have been attempts to establish a broader intercommunion between them, as in 1977 between the Greek Old Calendarist "Cyprianite" group and the Romanian Old Calendarists. ${ }^{43}$ Like in the previous case of the Old Believers, living in a Western setting does not necessarily render a group or an actor more tolerant and liberal, but, on the contrary, may lead to further isolation and radicalization. Needless to say, Old Calendarists deny any relationship with fundamentalism while accusing their opponents and critics of endorsing such an attitude. ${ }^{44}$

Another area in which rigorist mentalities and attitudes especially flourish, as the previously mentioned Esphigmenou case has shown, is the Orthodox monastic world, although rigorism is certainly not representative of the entire spectrum of Orthodox monasticism. ${ }^{45} \mathrm{~A}$ case in point, here, are the conversations the Scottish writer William Dalrymple held with a monk named Theophanes at the Greek Orthodox Mar Saba monastery in the West Bank. ${ }^{46}$ Despite the literary reworking of these conversations and their hilarious nature, one may hear what Father Theophanes appears to say there from many other Orthodox monks. AntiWestern, anti-Catholic and anti-Ecumenical mentalities, apocalyptic scenarios, Manichaean worldviews and conspiracy theories involving Jews, Freemasons and Western Christians remain exactly the same. Historically speaking, monastics always presented problems to the church hierarchy and the state (e.g. in Byzantium during the Iconoclastic controversy) due to their adamant, rigid and uncompromising views. Also, the fact that in many cases monastics enjoy a higher esteem among Orthodox believers due to their way of life than the members of the church hierarchy contributes to this tension. In reality, monastics are ready to differentiate themselves from the church hierarchy and the mainstream whenever they suspect compromises jeopardizing the Orthodox faith. It is thus not accidental that the above mentioned Old Calendarist movement initially found a fertile ground to spread among monastics (e.g. the Zealots on the Holy Mountain Athos), a fact that remains valid until today. Interestingly, recent attempts to renovate and modernize the Athos monastic community through subventions from the European Union have altered its historical and traditional profile to a large extent. Therefore, it came as no surprise that this process triggered again numerous rigorist reactions of all sorts. ${ }^{47}$

Similar attitudes and trends can be observed in many Orthodox monastic milieus in post-communist times (e. g. in Russia, Romania, Georgia). This has a lot to do with the challenges that these churches as a whole have faced in the postcommunist period, which, among other things, required a novel arrangement with

43

See Brady / Melling 2001, p. 355.

See Cyprian 1997.

For such variations within Orthodox Romanian monasticism, see Moga 2010.

See Dalrymple 1998, pp. 279-309.

See Fajfer 2013. 
the Western world and Churches. Such a transition was quite difficult; a fact explaining the numerous related tensions, debates and conflicts. It is in this context that Orthodox rigorists often became quite radical, aggressive and violent attempting to implement their ideas in society and voicing their protest against the dangers posed to the Orthodox tradition. This change can be explained by reference to the model of "de-secularization". ${ }^{48}$ Many post-communist countries have become the scenes of such violent incidents involving Orthodox actors who felt threatened by various novel developments, especially globalization, secularism, liberalism, pluralism and multiculturalism. ${ }^{49}$ For example, in Ekaterinburg in 1998 several theological books written by well-known Russian Orthodox theologians (A. Men', A. Schmemann, J. Meyendorff) were publicly burned at the courtyard of a theological seminary because they were considered to contain liberal and heretical doctrines in clear disagreement with the Orthodox faith. Interestingly enough, the local bishop Nikon (Mironov) seemed to have been involved in the whole incident,$^{50}$ which shows again the shifting boundaries between official church and rigorism. A year later, however, due to various other accusations the bishop was removed from his office by the Holy Synod of the Russian Orthodox Church.

In another case in Moscow, a modern art exhibition, entitled "Beware, Religion!" (Ostorozhno, religiia!), was organized at the Zakharov-Museum and Cultural Center in January 2003. This exhibition was, however, considered by several Orthodox hardliners as blasphemous, insulting and highly provocative, this is why they stormed the building and interrupted the exhibition causing serious damage to the exhibits. Remarkably, these rigorists were finally acquitted by the court, which in turn condemned the organizers of the exhibition to a financial penalty for insulting the religious feelings of the Orthodox population. ${ }^{51}$ Last, but not least, one has to mention the numerous cases of discrimination and harassment of non-Orthodox religious communities in Russia, mostly at a local level and often including violent actions, by Orthodox rigorists of varied provenance, which have been repeatedly publicized by the international fora on religious freedom. ${ }^{52}$

Such escalations of Orthodox-motivated violence do not however take place solely in post-communists contexts, but have also taken place earlier in the Orthodox world, mostly in a rigorist frame. After all, there is a long historical tradition of a specific Orthodox zealotry and rigorism, which, among other things, involved coercion, use of force and violence (e.g. in late antique Byzantium ${ }^{53}$ ).

48 See Karpov 2010.

49 See Verkhovskii 1998-99, pp. 109-112.

50 See Sourozh 73 (August 1998), pp. 43-45; Platonov 1998.

51 See Agadjanian 2014, pp. 98-109.

52 See Forum 18 News Service, available at: http://www.forum18.org/ [24.01.2016].

53 See some cases in Drake 2006. 
The murder of the Neoplatonic philosopher Hypatia in Alexandria in 415 by a Christian mob is a well-known case in point. To mention another modern case: in Greece in 1988 Orthodox rigorists attacked and caused damage to some cinemas in Athens where the film The Last Temptation of Christ, directed by Martin Scorsese and based on the homonymous and controversial novel by Nikos Kazantzakis, was shown. This was because the film was thought to offend the person of Jesus Christ and his divinity. ${ }^{54}$

The targets of rigorist reactions have also experienced transformation over the course of time. For instance, their traditional anti-Westernism was often transformed into an anti-Europeanism, especially after 1981 when Greece, as the first predominantly Orthodox country, officially joined the European Economic Community. Further developments within this frame always gave rise to Orthodox responses, as rigorists feared the loss of national sovereignty within the later European Union and the adulteration of the authentic Orthodox tradition. All these events were usually interpreted in apocalyptic terms as indicating the imminent coming of the end of the world. This also explains the 1998 massive reactions in Athens against the ratification of the Schengen Convention by the Greek Parliament (8 December 1997) ${ }^{55}$ Rigorist reactions may also turn against the perceived negative effects of the ongoing globalization process and the dangers it puts to local cultures. Thus, the cases of Orthodox rigorists involved in various anti-globalization protests against the "new world order" after the end of communism should also be mentioned.

Finally, another terrain, in which such rigorist mentalities and attitudes can be located, concerns the various converts to Orthodox Christianity across the globe. In fact, this is a growing phenomenon in several contexts, Western and nonWestern alike, with numerous and diverse manifestations. To be true, the conversion process is a multifarious and complex one and may have quite diverse consequences for the converted person. In our case, some converts are deeply affected by the fact that Orthodoxy claims to be the sole authentic form of Christianity going back to the Christian origins and the sole true religious faith in the world. To a large extent, this has to do with the consequences of the literal understanding of the term "Orthodoxy", which will be explained more extensively in the next section. Such intense, absolute and exclusive claims convey a strong sense of certainty and concomitant confidence with far-reaching repercussions. In this way, the phenomenon of converts, appearing sometimes as "born-again" Christians and expressing rigorist views, even against mainstream Orthodox believers, is not an exception. The usual features of rigorism mentioned above appear in many such cases in extreme and even idiosyncratic forms. Good examples thereof are the controversial street evangelist and cleric in the USA

54 See Makrides 1991, p. 59-60.

55 See Makrides 2004, p. 514. 
Nathanael Kapner, who is a convert to Orthodoxy from Judaism, ${ }^{56}$ and the writer, film director and public speaker Frank Schaeffer ${ }^{57}$. All this is indicative of the rich variety of the forms and ways in which Orthodox rigorism makes itself active, known and publicly visible.

\section{Background, development and transformation of Orthodox rigorism}

In view of the specificities of Orthodox rigorism, it appears necessary to make them clearer and more understandable by examining the background, the development and the later transformations of the entire phenomenon. Although my main focus here lies more on its modern aspects, the long socio-historical background of Orthodox rigorism should also be taken into account. No doubt, as already mentioned, cases of rigor, zealotry and extremism can be observed throughout the history of Orthodox Christianity, being motivated, among other things, by the unshaken belief in the singular and exclusive correctness and absoluteness of the Orthodox faith. Although there is a line of continuity, modern Orthodox rigorism should be mainly associated with the radical changes that took place from the early modern period onwards and have posed serious challenges to European Christianity as a whole. In discussing the modern background of Orthodox rigorism in a succinct way, it is helpful to distinguish between the endogenous and the exogenous causes of the phenomenon. The endogenous ones refer more to cardinal and interrelated factors germane to the overall articulation and development of Orthodox Christianity across time and its own historical formation. The exogenous ones relate more to specific influences and challenges to the Orthodox world coming from outside (mostly and usually from Western Europe in modern times), which triggered various responses and reactions including rigorist ones in specific Orthodox contexts.

Starting with the endogenous causes, we should first mention the catalytic significance that the historical East-West opposition had in Europe from Byzantine times and especially in the wake of the separation of the two churches. There already exists quite a huge array of literature about the far-reaching and multidimensional consequences of the "Great Schism" (1054) between East and West. Orthodox anti-Westernism is nowadays still a resilient and widespread phenomenon among various Orthodox circles including the rigorists. When the ailing Pope John Paul II visited Athens on May 2001 for just one day, there were massive Orthodox reactions, especially initiated and coordinated by various

56 See Nathanael Kapner on rationalwiki, available at: http://rationalwiki.org/wiki/ Nathanael_Kapner [24.01.2016].

57 See Schaeffer 1995 and 2002. 
rigorist organizations and actors. ${ }^{58}$ This is because in the eyes of these Orthodox, the Pope personified the entire Roman Catholic Church, which has been inimically viewed for many centuries as fallen, heretical and the "abode of the Antichrist", and is still considered as a major threat to the Orthodox world. This is typical of the enemy syndrome and defensive attitudes characterizing generations of Orthodox Christians including the rigorists, both historically and at present. Interestingly enough, the East-West opposition did not remain solely a religious one, but included many other non-religious aspects. Western Europe and - more broadly speaking - the West came to signify for numerous Orthodox the places out of which dangers for the Orthodox East had solely originated. It is about the "secularization" of the original Orthodox anti-Westernism and its incorporation into a wider anti-Western scheme. Characteristically, this anti-Western frame is not supported solely by Orthodox actors, but is endorsed under specific circumstances by secular ones for various reasons (e.g. political, social, cultural). Nevertheless, the Orthodox dimension of anti-Westernism remains the cardinal and prominent one in the rigorist worldview and discourse, as they prefer to evaluate past and current events according to their own specific criteria (e.g. eschatological, apocalyptic, Manichaean). On the contrary, the official church hierarchy generally is more diplomatic and careful in its relation to the Western Churches. In sum, the strong anti-Western sentiments of the rigorists should be placed on this broader historical Orthodox canvas of anti-Westernism in order to be adequately understood. ${ }^{59}$

Another vital factor in this category has to do with the particular understanding of the term "Orthodoxy" in our milieu across history ${ }^{60}$ which should be also examined against the background of the consequences that the establishment of monotheistic religions brought about historically. ${ }^{61}$ No doubt, this term is applied to a plurality of different cases today, both in religious and non-religious contexts. The potential relations between fundamentalism in general and the notion of Orthodoxy have also been discussed. Jaroslav Pelikan has tried to dissociate the teachings of modern American Protestant fundamentalism from those of Christian Orthodoxy; namely from the mainstream of the historical development of Christian doctrine, both in its pluralism and its underlying consensus. ${ }^{62}$ Yet, in our case we are referring to a particular literal understanding of the term "Orthodoxy", which has been deeply ingrained as such in Orthodox Christian consciousness over the centuries. The Orthodox are subsequently seen as the only ones in possession of the sole right and exclusive religious faith in the entire world, based on God's revelation, from which Western Christians have deviated. The

\footnotetext{
$58 \quad$ See Seraïdari 2002.

59 See Makrides / Uffelmann 2003.

60 See Makrides 2001-2002 and 2014a.

61 See Stark 2001.

62 See Pelikan 1990.
} 
right Christian faith and its exact, unaltered preservation were thus regarded as extremely important in life and were also inextricably connected with the salvation of the soul and eternal life after death. Already in Byzantine times and especially in the wake of the East-West church conflicts, the issue of preserving the right Christian faith became a most central one. In many cases, possessing Orthodoxy was regarded as the highest achievement one could ask for in life. Out of this strong and pervasive conviction, various socio-cultural consequences arose historically in the Orthodox world. For example, in the modern period several Orthodox Christians tried to compensate for the deficits of their societies by emphasizing the insuperable value of Orthodoxy that they always possessed. In their view, this was the sole true criterion of superiority and electedness, clearly distinguishing the authentic Orthodox East from the fallen Western Europe. The latter was successful solely in numerous trivial mundane areas, yet it lacked Orthodoxy, which in fact rendered it inferior. Such and similar arguments were formulated and disseminated by the Orthodox in many cases, especially when a comparison between the achievements of East and West was at hand. ${ }^{63}$ All this has to do with the multiple socio-cultural consequences of the literal understanding of the term "Orthodoxy" in the past and at present, which is rather unique in our case. Such consequences can also be observed among Orthodox rigorists, even in extreme forms. Many aforementioned special and other features of Orthodox rigorism have a lot to do with this particular literal understanding of Orthodoxy, which in the end resorts to the ideology of "Orthodoxism". This includes, among other things, a sense of superiority, triumphalism, self-complacency and self-sufficiency, Manichaean mentality, enemy syndrome, conspiracy theories, and last but not least, the use of violence. The latter is usually justified by reference to the right, legitimate and higher aims of Orthodox rigorism. In sum, the above phenomenon can be observed with varying intensity during different periods of Orthodox history, while the rigorists are part of this long chain of understanding and internalizing Orthodoxy in such a particular way.

A related important factor, on which the rigorists also place particular emphasis, relates to the position of tradition within Orthodox Christianity as a whole. By comparing it with the Roman Catholic or the Protestant cases, it becomes obvious that Orthodox Christianity is much more traditional. After all, it also claims to be the only church to have kept the authentic Christian tradition without major or minor innovations across time. All this creates quite a traditionalistic environment that neglects and denies reforms altogether while always idealizing the "idyllic past" and its normative character in evaluating the present and the future situation. ${ }^{64}$ Remarkably, this kind of Orthodox traditionalism has often overcome its religious borders historically and has become more influential in society, politics and culture - again a "secularization" of this initially religious

63 See Makrides 2006.

64 See Ramet 2006. 
phenomenon. For the rigorists once more, to be connected with this long historical chain of upholding the Orthodox tradition intact is regarded as a sine qua non and becomes the source of their strong motivation and sense of electedness. Especially under the conditions of modernity and postmodernity, as well as the ongoing globalization process, rigorists fear the loss or the adulteration of the Orthodox tradition, a fact explaining their extensive mobilization and continuous reactions. It has been mentioned before that fundamentalism for many reasons should not be equated to a mere traditionalism, although this has been also attempted for the Orthodox case. ${ }^{65}$ Yet, from the above analysis it becomes obvious that here we are dealing with one of the particularities of Orthodox rigorism due to its specific and omnipresent relationship to tradition.

Taking into consideration the exogenous causes that have led to the rise of Orthodox rigorism, we should look for its specific socio-historical background, as well as for its later transformations and contemporary socio-cultural contexts. These causes should be primarily sought from the early modern times onwards, as the Orthodox world in its different contexts (e.g. the Russian Empire, the Balkans under Ottoman rule) has increasingly come into contact with Western modernity and was influenced accordingly in many domains. It was a process that created quite serious engagements, tensions, debates and conflicts in the Orthodox world and led in many cases to deep cleavages in the respective societies between proWestern and anti-Western trends, movements and actors. As was to be expected, the Orthodox side was overwhelmingly aligned with the anti-Western camp and at times played the leading role in the respective reactions. It was exactly this wide exposure to Western influences over the last centuries that led, among other things, to the rise of modern Orthodox rigorism.

Such developments can be clearly observed in the Russian Empire especially after the Westernizing and modernizing efforts of Tsar Peter I, which were continued throughout the $18^{\text {th }}$ century under the decisive influence of West European Enlightenment. The latter, in fact, set the main premises for the Western program of modernity and its wider application. ${ }^{66}$ The related socio-cultural changes were often perceived as dramatic crises and led to various rigorist reactions in Russia, including those of the previously mentioned Old Believers, who saw the clear evidence of the distancing from the pure Orthodox tradition in the Westernization process. Given that the official church was in many ways tightly bound to the Tsarist regime and did not present any serious challenge to the attempted societal changes under Western influence, rigorist reactions here originated mostly from the monastic milieus or independent Orthodox believers and thinkers. The related problems became more evident especially during the $19^{\text {th }}$ century when the key problem of Russia's identity and future course was strongly debated among a large variety of competing ideological currents and movements, representing at

65 See Yannaras 1992.

66 See Eisenstadt 1999, pp. 119-135. 
times diametrically opposed views and attitudes. Many of them stood in different forms under the formative influence of the Orthodox tradition (e.g. the Slavophiles), yet they did not represent stricto sensu rigorist reactions. As already mentioned, not all Orthodox protest formations and actions fall under the category of rigorism. Some rigorist views can be located in the movement of the socalled Pochvenniki, namely those close to the "soil" of the Russian land and people, who were mostly grouped together around a journal named Vremia (Epoch). At the beginning, they intended to reconcile the Westernizers and the Slavophiles and received various influences besides the Orthodox ones. Yet, this initial spirit soon faded, and they started strongly supporting the indigenous elements of Russian culture (e.g. autocracy, anti-Westernism, nationalism) and "native soil conservatism" ${ }^{67}$. The exact boundaries between the above groups were, however, never strict and clear. The well-known writer Fyodor M. Dostoevsky thus had close relations both to the Slavophiles and the Pochvenniki. Characteristically, there is a line of continuity between the Pochvenniki movement and contemporary Orthodox rigorists in post-Soviet Russia. ${ }^{68}$

Analogous developments can also be observed in the Orthodox Balkans under Ottoman rule from the second half of the $18^{\text {th }}$ century onwards, again under the decisive influence of West European Enlightenment. In this context, rigorist reactions had more to do with the marginalization of the greater societal role of the Patriarchate of Constantinople and - more broadly speaking - of an Orthodoxbased worldview in society and culture in the wake of Western secularizing ideas and practices. These reactions exhibited various sectarian and utopian elements of an all-encompassing transcendental order, a central component of proto-fundamentalist movements. ${ }^{69}$ The so-called Kollyvades controversy over the issues of memorial services and frequent communion, which erupted in the 1750s on the Holy Mountain Athos and later spread in other areas, demonstrated such characteristics. In fact, it also had to do with the growing Western influences at that time and their potential threat to the inherited Orthodox tradition. Many of the protagonists of the Kollyvades movement clearly expressed such a rigorist mentality, which forced the official church to take measures against and to condemn them. The spirit of early Orthodox rigorism lingered on in the $19^{\text {th }}$ century after the foundation of the Greek state in 1830 and was again expressed by various actors, movements and organizations in different forms, mostly in strong antiWestern settings, ranging from a critique of official church decisions to reactions against academic theology. Numerous Orthodox believers thought that the church was allowing dangerous compromises to take place and that counteraction to stop the demise of Orthodoxy was imperative. ${ }^{70}$ The subjection of the

67 See Dowler 1983.

68 See Aksiuchits 1990; Selbach 2002, pp. 140-143, 147-152.

69 See Eisenstadt 1999, pp. 25-27.

70 See Giannakopoulos 1999, pp. 37-196. 
church to the state during the regime of the Bavarian King Otto (1833-1862), the unilateral declaration of its autocephaly and independence from the Patriarchate of Constantinople in 1833, and the closing of numerous monasteries throughout the country were among the radical changes that triggered rigorist reactions and popular protest movements, such as the one led by Christophoros Panagiotopoulos, alias Papoulakos (1770-1861). The socio-religious criticism of the monk Kosmas Flamiatos (1786-1852) and that of the lay popular preacher Apostolos Makrakis (1831-1905) are also cases in point. Aside from this, Orthodox rigorists still found ways to cooperate with the church in the second half of the $19^{\text {th }}$ century, especially in the context of the virulent Greek nationalism and irredentism.

In the course of the $20^{\text {th }}$ century many predominantly Orthodox countries were found under a long communist rule (1917-1991), and this of course heavily affected the respective positions of the Orthodox Churches, which were subjected to the inimical attitude of, and often to persecution by, the communist regimes. This was a serious curtailment of Orthodox rigorist reactions in these countries. Yet, such attitudes were clearly observed among various church formations that had originated in this context and later became active outside the realm of communism. The most characteristic case is that of the Russian Orthodox Church Outside Russia (ROCOR), which separated itself from the Moscow Patriarchate in 1927 and developed further in the West, endorsing in many cases rigorist positions (e.g. anti-Ecumenical). It also cooperated and entered into church communion in 1994 through a formal act with various groups of Old Calendarists in Greece, Bulgaria and Romania. This lasted until 2006 when the ROCOR started discussions about its reunion with the Russian Orthodox Church, which formally took place in 2007. In addition, back in 1955, some bishops from the ROCOR had enabled the canonical continuity of succession within the Old Calendarist movement by consecrating an archbishop and other bishops. ${ }^{71}$ The latter, as already mentioned, was the outcome of the increased openings of the Patriarchate of Constantinople towards modern demands (e.g. on the calendar issue), but also towards other Christian Churches (e.g. with the encyclical of 1920 "To the Churches of Christ wheresoever they may be") ${ }^{72}$ For the rigorists, this attested not only to the "heresy of Ecumenism", but also to the internal decaying of Orthodox Church leaders supporting such dangerous innovations. ${ }^{73}$ All this had in turn serious implications for local Orthodox Churches, such as the Greek one, causing again rigorist opposition that culminated in the Old Calendarist schism. ${ }^{74}$

Orthodox rigorist reactions were intensified even further in the second half of the $20^{\text {th }}$ century due to the ongoing transnational process of globalization, which

71 See Brady / Melling 2001, pp. 354-355.

72 See Keleher 2001.

73 See Ware, 2002, p. 7.

74 See Kitsikis 1995, pp. 8-19. 
entailed a series of economic, political and cultural transformations including the feared erosion of local religious and national identities. In fact, the connection of the globalization process with the intensification of fundamentalist and other related movements and reactions worldwide has been emphasized by many theorists. ${ }^{75}$ The post-World War II period saw namely the emergence of common transnational patterns in all domains, from global polity and economy to religion, which were connected with a weakening of Western hegemony and concomitant new challenges for local cultures. ${ }^{76}$ Globalization went hand in hand with an unprecedented influx of new lifestyles, ideas and morals, which was perceived as a serious problem by the rigorists. The present global syncretistic environment with its ideals of pluralism, secularism, multiculturalism, tolerance, and liberalism put the rigorist view on the uniqueness of the Orthodox truth to the test and threatened their exclusivity and superiority claims about an Orthodox hegemonic culture. It is not an accident, for example, that rigorists have been very critical to the adhesion of Greece to the European Economic Community in $1981 .^{77}$ In connection with this, the current postmodern era of change, relativism, ambiguity, contingency and uncertainty has also prompted fundamentalist particularistic reactions of all kinds, ${ }^{78}$ and the same holds true for the Orthodox rigorists as well.

A new era of an Orthodox rigorist resurgence took place after the collapse of the communist regimes and the concomitant liberalization of religion in the respective countries. The Orthodox Churches and cultures of the former Eastern Bloc were suddenly found in a period of transition and restructuring, which included a lot of unexpected serious challenges within the current global environment. One such challenge related to coming to terms with religious and cultural pluralism. It is thus not accidental that Orthodox rigorism was often intensified in such contexts and received wider support from numerous believers, especially as the boundaries between the religious and the secular shifted causing major culture wars. ${ }^{79}$ In post-Soviet Russia several Orthodox actors today exhibit key rigorist characteristics, are critical of the pro-Western orientations of non-Orthodox or secular actors, oppose inter-Christian dialogue and Ecumenical initiatives, and criticize the official church of endorsing compromising positions. ${ }^{80}$ In addition, we can witness here the rise of various Orthodox apocalyptic and eschatological scenarios about the imminent end of the world, the coming of the Antichrist, the Jewish and Masonic plan for worldwide domination and numerous other conspiracy theories (e.g. about the ritual murder of the last Tsarist family by the

\footnotetext{
75 See Antes 2002.

76 See Eisenstadt 1999, pp. 135-149.

77 See Giannakopoulos 1999, pp. 347-366.

78 See Bauman 1997, pp. 165-185.

79 See Kishkovsky 2000.

80 See Kostiuk 2000; Verkhovsky 2002; Walters 2007; Stieger 2011; Kadotschnikow 2014.
} 
Bolsheviks). It should not be forgotten that the well-known anti-Semitic conspiracy text The Protocols of the Elders of Zion was forged and first published in the Russian Empire at the beginning of the $20^{\text {th }}$ century, whereas it also enjoys great popularity in post-Soviet times. ${ }^{81}$

All this often brings Orthodox rigorists closer to various other groups in contemporary Russia, including monarchists, nationalists, fascists, Eurasianists, or neo-communists. Despite their differences in ideology, orientations and objectives, they all aim in one way or another to defend the Orthodox and national character of the country from an inimical, Western-led takeover. ${ }^{82}$ Further, rigorist attitudes flourish in various Orthodox organizations and brotherhoods of lay believers, headed by a lay elder or a clergyman, which are not under the direct control of the church (e.g. the Obshchestvo "Radonezh"). ${ }^{83}$ The boundaries between these brotherhoods remain generally fluid. Although there are certain more liberal ones, in most cases they exhibit the usual features of Orthodox rigorist mentality (e.g. anti-Western, anti-Ecumenical, xenophobic) ${ }^{84}$ The official church has repeatedly tried to control and coordinate the activities of these brotherhoods through a "Union of Orthodox Brotherhoods", founded in 1990. Yet, it is clear that this was not the case in the long run, simply because of the extreme rigorist views and tendencies flourishing within such milieus, which are incompatible with the rather moderate attitude of the official church. ${ }^{85}$

Even if not in control of the church hierarchy, rigorists in post-communist Russia constantly put pressure on it, while their positions are often reflected in official church statements and policies. ${ }^{86}$ Thus, they often force the church to criticize or take measures against liberal and reformist Orthodox priests (e.g. Father Georgii Kotchetkov), who are considered dangerous for upholding the authentic Orthodox tradition. ${ }^{87}$ Once more, an absolute distinction between the church hierarchy and the rigorists becomes difficult, as they often share more than they openly confess; for example, a conservative discourse presenting Orthodox Russia as an effective antidote against the constant decline of the fallen modern world due to Western influences. ${ }^{88}$ There have also been attempts at a politi-

81 See Hagemeister 2006. This text enjoys popularity in other Orthodox cultures as well, not only among rigorists, but also among members of the church hierarchy. Concerning Greece, see Psarras 2013.

82 See Shenfield 2001, pp. 48-73; Shnirelman 2015.

83 See Verkhovskii 1998-99, pp. 98-109.

84 See Rock 2002 and 2003; see also Rousselet 1993.

85 See Rock 2003, pp. 339-342; see also Mitrofanova 2014.

86 See Selbach 2002.

87 See Sourozh 56 (May 1994), pp. 53-54;58 (November 1994), pp. 47-48;85 (August 2001), pp. 50-51; see further Selbach 2002, pp. 143-146; Agadjanian 2014, pp. 191-207; Brüning 2016.

88 See Verkhovsky 2006. 
cization of Orthodoxy, in which rigorist circles are sometimes actively involved. ${ }^{89}$ Among other cases, this form of "political Orthodoxy" has already been observed in the Ukraine during the 2000s and more recently during the Russian-Ukrainian conflict in the separatist region of Eastern Ukraine (Luhansk and Donetsk), receiving support from various church circles including official ones. ${ }^{90}$ Despite all this, we should not overlook the fact that post-Soviet Russian Orthodoxy exhibits further characteristics that do not belong to the above categories. ${ }^{91}$

Taking a look at some other cases, the consecutive wars during the 1990s and the subsequent final dissolution of Yugoslavia have also caused various reactions on the part of Orthodox Serbian rigorists. These have a strong anti-Western tradition of their own, which has re-emerged after communism in novel forms ${ }^{92}$ for example, through the ultra-Orthodox brotherhood Obraz (Honor), through the canonization of conservative and anti-Western clerics, such as Nikolai Velimirović (1881-1956) and Justin Popović (1894-1979), or through the critique of liberalminded clerics, such as Radovan Bigović (1956-2012). In general, traditionalist and conservative attitudes predominate in the post-communist period, which is understandable in the light of the radical socio-political and cultural changes effected there. Orthodox rigorists have also interpreted the deep and tenacious financial crisis of Greece since 2009 in similar, conspiracy-driven negative colours. ${ }^{93}$ The "new world order", brought about by several ground-breaking changes (political, military, economic, cultural etc.), is usually interpreted by the rigorists according to their own conspiracy logic.

As already mentioned, Orthodox rigorists are not found today solely in the historical Orthodox heartlands, but are also spread in the Orthodox diaspora across the globe and in quite different settings. The phenomenon of growing Orthodox transnationalism ${ }^{94}$ has also contributed to this internationalization of rigorism with diverse consequences. One may thus find Old Calendarists operating in the USA (e.g. the Center for Traditionalist Orthodox Studies, Etna, CA), and elsewhere in the West, opposing not only Ecumenism and the calendar reform, but the overall threat of modernism to the church. They sometimes attempt to create a broader pan-Orthodox rigorist front against the respective church hierarchies and try to keep the outer boundaries of Orthodox identification as strict as possible; for example, by outright negating the canonicity and legitimacy

89 See Mitrofanova 2004.

90 See Hovorun 2016, pp. 58-60.

91 See Agadjanian 2014 and 2015.

92 See Buchenau 2006, 2011a and 2011b.

93 See online article "Senior Greek Priest Blames Jews for Greece's Financial Problems", available at: http://www.haaretz.com/jewish-world/senior-greek-priest-blamesjews-for-greece-s-financial-problems-1.332131 [24.01.2016].

94 See Roudometof 2015. 
of the sacraments (e.g. baptism) performed by non-Orthodox Christians. ${ }^{95}$ In other cases, tensions arise when Orthodox monastic elders ( $\gamma \varepsilon \dot{\varepsilon} \rho \nu \tau \varepsilon \varsigma$ or startsy) try to disseminate their rigorist views and practices to Orthodox communities in Western settings; a process that may lead to internal tensions and divisions between traditionalist and more progressive members within such communities. ${ }^{96}$ All this happens because of the widespread belief among rigorists and other Orthodox believers that these monastics, due to their ascetic life and contact with God, possess a particular understanding of the Orthodox truth (a kind of hidden, esoteric knowledge), as well as special abilities (e.g. in foreseeing future events). It goes without saying that such persons are then turned into the main "guardians of Orthodoxy", and their popularity and authority are extremely enhanced, sometimes at the expense of official church positions. But the same may happen in the historical Orthodox heartlands as well, especially when not only monastic elders, but also young, inexperienced and immature clerics (mladostarchestvo) acquire such a spiritual authority in an Orthodox community, thus again causing various problems and tensions. ${ }^{97}$

Finally, it is interesting to mention that Orthodox rigorism relates to the notion of the decoupling of religion and culture, elaborated by Olivier Roy. ${ }^{98}$ This is not understood here in the sense of a de-territorialization of religion in the wake of its separation from a local culture due to the process of globalization. Neither has it to do with the quest for a "pure religion" independent of cultural variations and local influences. It is more related to the fact that rigorists oppose a transformation of religion into a culture, basically understood as a profane entity, which is a dominant trend in the context of secularization and the emphasis put on worldly concerns. Thereby religion loses its primary character and is transformed into a broader and non-binding element that belongs to a rather all-inclusive cultural frame of reference. In this sense, culture is regarded as a threat, given that ideally - according to the rigorist worldview - everything has to be or to become "religious". It is thus a basic conviction of the rigorists that the Orthodox Church has gradually moved in this direction, lost its critical, prophetic voice in society, and surrendered itself to the growing pressure of the surrounding secular culture. As a result, it was forced to make various minor and major compromises that jeopardize the highly cherished right faith, namely Orthodoxy. In the end, to be an Orthodox today means belonging to a specific culture, which naturally includes much more than religion and in which the Orthodox factor plays more or less an insignificant, decorative role. By contrast, according to the rigorists, the church should be liberated from this adulterating "cultural captivity" and get rid of its mere characterization as a coincidental feature of a specific cultural identity. As a

\footnotetext{
95 See Morris 1998. For a characteristic case, see Cavarnos 1992.

96 See Cimino 2011.

97 See Hovorun 2016, p. 57; see also Vladimir 2005.

98 See Roy 2010.
} 
consequence, patterns of modern religiosity, such as when Orthodoxy is understood as a form of "diffused religion", as an abstract, non-normative category devoid of any concrete practical consequences, and as a cultural asset and integral part of a modern broader cultural identity, ${ }^{99}$ are repudiated by the rigorists. On the contrary, they support a firm, conscious and genuine attachment to the Orthodox tradition and a real and precise familiarity with its teachings, practice and spirituality. Therefore, it is no surprise that they criticize the majority of the mainstream believers as exhibiting signs of Orthodox anemia, because the latter go to church only on selected occasions (e.g. great feasts or rites of passage) and are religious only superficially and nominally. Needless to say, all this turns against the secularization process, which entails significant transformations of religious belief and belonging in the postmodern context.

\section{Are there any Orthodox resources against rigorism?}

The above elaborations on the various facets of Orthodox rigorism in the past and at present do not signify that this is the most prominent feature of Orthodox Christianity. The latter constitutes a much more pluriform and diversified system with a great variety of aspects and expressions. The mainstream Orthodox believers, being attached rather to a cultural form of Orthodoxy, do not support rigorism and do not share its views on church and society. In other words, it is not amiss to argue that rigorism is a marginal phenomenon within the Orthodox world, also from a quantitative perspective.

Yet, there are two things to be taken into account at this point: first, due to the rigorists' relations with the official church hierarchy and their mobilization power, rigorist attitudes and actions become at times quite visible in society, thus they may attract not only the occasional curiosity of outside observers, but also greater attention from various social strata. Second, rigorism receives support, both directly and indirectly, from the fact that the Orthodox Christian milieu still remains, to a large extent, quite traditionalist with many respective characteristics, a fact that differentiates it substantially from the respective Protestant and Roman Catholic cases in Western Europe. It is still a milieu that cherishes the unquestioned authorities of the past and lacks self-critical attitudes and a constructive view of the future. Therefore, it is not accidental that modern theological methods and hermeneutics have so far found little fertile ground to develop in Orthodox contexts. All this is particularly conducive to the emergence of Orthodox rigorism.

In order to better capture the specificities of Orthodox Christianity and its multiple repercussions, one must take into consideration the fundamental fact that its encounter and relationship with modernity - in contrast to West European

99 See Makrides 2003, pp. 211-215. 
Christianity - were partial, fragmented, limited and incomplete. It thus never had the consequences that were made possible in the West, a development that in the long run changed the profiles of the respective churches there. ${ }^{100}$ This concerns a variety of key issues that have shaped modern cultural values, ranging from individual human rights and personal autonomy to liberal, pluralist and secular ideals. Orthodox Churches, however, still have great problems coping with these developments, simply because they have never experienced the processes and changes that led to them in a full and constructive way. The post-communist Russian Church with its current critique of the basic tenets of Western modernity including individual human rights is a clear case in point. ${ }^{101}$ The same concerns other Orthodox milieus in post-communist times as well ${ }^{102}$, such as Georgia ${ }^{103}$ and Romania ${ }^{104}$. Interestingly enough, similar problems can also be observed in Orthodox Greece, a country that always belonged to the Western orbit of influence. In general, the Orthodox discourse still shows certain clear predilections that are closely related to the lack of a productive encounter with modernity. As a result, it often tries to answer or solve modern problems and challenges by reference to a pre-modern logic and frame of ideas, based on the authorities of the past (Church Fathers etc.). By contrast, all this may explain why West European Christianity exhibits other facets. It has already had a long and painful, yet constructive encounter with modernity; for example, with the Enlightenment, which led to its greater rationalization and secularization. This also explains why we do not commonly find strong fundamentalist movements on the West European religious scene contrary to the USA, where the impact of the Enlightenment was quite a different one. An absence of the Enlightenment influence can also be claimed for Orthodox Eastern and South Eastern Europe, ${ }^{105}$ which may also account for several of its religious and cultural idiosyncrasies including rigorism.

It is in this context that Orthodox rigorists may expectedly not only exist and survive, but also sometimes thrive and flourish. The whole Orthodox environment is hence conducive to their genesis and rise in the first place, especially as they tend to be more extreme in their critical stance towards, or negation of, modernity and of the spirit underlying it. In many respects, they represent pretty well what Olivier Roy has called "holy ignorance" ${ }^{106}$. This is because their understanding of the Orthodox tradition is reductionist, fragmented and lacks the sophistication and the critical awareness induced by sound historical analysis, modern con-

100 See Makrides 2012; Kalaitzidis 2015.

101 See Agadjanian 2014, pp. 113-174, 243-264. See also various articles in Makrides / Wasmuth / Kube 2016, pp. 27-136.

102 See various cases in Clark 2000.

103 See Crego 2014.

104 See Turcescu / Stan 2014.

105 See Kitromilides 2016.

106 See Roy 2010. 
textual thinking and the ability for self-reflection. ${ }^{107}$ They sense the need to objectify their beliefs in such a way as to feel absolutely secure and to cast away any external influences or critical views. For them, to believe, even blindly and dogmatically, is far more important than to try to know better. For example, their attachment to the Bible and other authoritative texts of Orthodox Christianity or to the Church Fathers is uncritical, mythical, and credulous. ${ }^{108}$ Modern hermeneutics or other methods of examining past texts and their heritage (e.g. the historical-critical one) are practically unknown in rigorist milieus. They usually speak of the incomparable value and significance of the Orthodox tradition as a taboo, yet they basically "ignore" how this tradition came about, what exactly it contains, and how it should be interpreted today. All this is, however, of no interest to them, as this mostly irrational, instinctual, and naïve adherence to what they consider as "sacred" conveys to them certainty, security and confidence. It goes without saying that this attitude reflects the traditional Orthodox anti-intellectualism, which is expressed in numerous forms (e.g. as a critique of modern academic theology ${ }^{109}$ ).

Does all this mean that rigorism goes unchallenged and gets no response or critique at all within Orthodox contexts? In fact, the opposite is the case. First, the church hierarchy, either officially or through its individual members, often denounces the rigorist views, actions and excesses as deviating from, or as not expressing, the genuine Orthodox tradition. This is because rigorist activities in many cases do not please the official church, as they may be outspokenly directed against it. On the other hand, as already mentioned, the church may use and instrumentalize rigorists for various purposes, and there are church hierarchs who are close to the rigorists and their perceptions while supporting them. This ambivalent attitude complicates the whole situation and explains why such official church critique against the rigorists does not bear fruits and remains mostly ineffective.

More substantial critique against rigorism originates from other Orthodox milieus, namely from independent clerics, lay theologians and other thinkers dealing with Orthodox Christianity, who are in a better position to realize the problems created by rigorism and attempt to find ways to neutralize this phenomenon. This is attempted not only in the historical Orthodox heartlands, but also in the Orthodox diasporic communities, as many Orthodox there can make pertinent comparisons between Orthodox rigorism and other forms of fundamentalism. Here the need to avoid extreme positions and to follow a rather middle and reasonable way is mostly emphasized. This can be basically accom-

107 See the words of the previously mentioned monk Theophanes: "I've stopped reading books myself [...] The Divine Liturgy contains all the writing I need. Once you've read the Word of God everything else becomes very dull." (Dalrymple 1998, p. 290).

108 See Demacopoulos 2015; Hovorun 2016, p. 57.

109 See Metallinos 1989. 
plished through a moderately critical view on tradition, as the danger to fall into an arid traditionalism remains always imminent. Seminal Orthodox theological thinkers of the $20^{\text {th }}$ century are also adduced to show how one should deal with tradition constructively and creatively and not follow it blindly. ${ }^{110}$ In addition, the involvement of the Orthodox Churches in the broader Ecumenical Movement exhibits numerous positive and constructive sides, which clearly speak against the anti-Ecumenism of the rigorists and of certain church circles. In fact, the Orthodox Churches historically contributed a lot to the Ecumenical Movement during the $20^{\text {th }}$ century and in many cases played a pioneering role. ${ }^{111}$ Despite various problems and anti-Ecumenical reactions in post-communist times, most Orthodox Churches are still actively involved in numerous related endeavors and accomplish a great deal internationally. During various consultations (e.g. at the Pan-Orthodox Conference in Thessaloniki, 29 April -1 May 1998) it has also been clearly emphasized that the eventual official Orthodox dissatisfaction with some developments within the Ecumenical Movement should not be confused with the criticism exerted on it by various Orthodox rigorists, given that these two have quite different causes, orientations and purposes. ${ }^{112}$

In most times, the critique against rigorism is articulated in a broader frame, namely by indicating and emphasizing the pressing need for the Orthodox Church to come to terms in more constructive ways with the heritage of modernity. It is well-known that this is a long and also painful process, as it involves considerable changes and an outspoken reform mentality. As a result, it cannot take place automatically, and judging from the already strong reactions to such a kind of Orthodox reform thinking, it will not be an easy task without conflicts. Yet, it is more than clear that any meaningful opposition to rigorism is closely connected with such broader self-critical developments within the Orthodox world. In a way, the Orthodox should learn from the Protestant and Roman Catholic experiences with modernity and formulate their own agenda and strategy of dealing with it. They also have to overcome their tenacious and arid anti-Westernism and look for ways of a more fruitful encounter with the West and its historical heritage (e.g. the Enlightenment tradition). As already mentioned, there are many signs that such fermentations in various forms are taking place within the Orthodox world of today, even at the official church level. Such is the case of the Volos Academy for Theological Studies in Greece, a progressive forum of theological reflection in close relationship with the surrounding secular culture under the aegis of the local diocese ${ }^{113}$ But again this specific endeavor has encountered quite a few reactions and negative criticisms, not only from the rigorist camp, but also from certain traditionalist church hierarchs and other Orthodox actors. It becomes then clear

110 See Plekon 2010; Kattan 2015.

111 See Kalaitzidis et al. 2014.

112 See Makrides 2004, p. 518.

113 See Kalaitzidis 2015, pp. 85-87. 
that Orthodox Christianity still exhibits strong and widespread conservative predilections and leanings that may inhibit real reforms to take place. Be that as it may, we are still at the beginning of a long-term process that will possibly enable the emergence of a new and reformed Orthodox world in the future.

Generally, church leaders tend to underestimate the importance of rigorism or to disqualify it as a foreign intruder into the pristine Orthodox tradition and as an ineffective strategy in the modern global environment. ${ }^{114}$ At the same time, they try to control its bearers and soften their extremism, so that they may use them for various purposes. In this article, however, the main goal was not so much to locate foreign influences upon Orthodox rigorism, such as from Protestant fundamentalism, but rather to assess its presence in its real dimensions within the broader Orthodox landscape by analyzing its main manifestations, socio-cultural background and evolution, as well as its ambivalent relations with the church hierarchy. Bearing all this in mind, it is likely that the particular coexistence between the official church and the rigorists will continue in the years to come, together with the phases of their collaboration, as well as of their conflict. In all probability, rigorists will not gain control of the official church in the near future, but the pressure that they may exert on it will certainly continue to be a serious factor in shaping future church politics. No doubt, the ongoing globalization process and its further implementation will have far-reaching consequences for Orthodox local identities and will probably exacerbate even stronger rigorist reactions. This may lead to unexpected alliances among the opponents of globalization, regardless if they originate from quite diverse backgrounds. From this point of view, it makes little sense if one classifies Orthodox rigorists, Protestant fundamentalists and all similarly-minded groups in a simplistic way as irrational fanatics and threats to world stability. Aside from the conflicts and polarizations produced by such protest movements, it is more interesting to assess their open and patent role in society and how they are linked to the establishments, both religious and secular, that they most vehemently criticize. Such an antinomy can be clearly observed, as already mentioned, on the Holy Mountain Athos, where this traditionally antiWestern monastic community receives today large amounts of money from the European Union for restoration and modernization works; a process that, however, threatens to alter substantially its time-honored image. It is also exciting to examine what makes such conservative movements like rigorism appealing, attractive and quite successful among many categories of people, sometimes in clear opposition to various liberal, progressive and trendier religious groups. ${ }^{115}$ In our specific case, the previously analyzed endogenous causes for the genesis and the development of Orthodox rigorism may account for this.

No doubt, Orthodox rigorism appears to be at times vehemently anti-modern and anti-Western, yet at the same time it deals with modernity in its own manner.

114 See Papandreou 2000, pp. 245-251.

115 See Kelley 1972. 
The latter ranges from the rational goals set and the modern means used to realize them to the "Jacobin", all-encompassing and even totalitarian component of its ideology. ${ }^{116}$ The relationship of Orthodox rigorism with the modern world is not only antagonistic, but profoundly ambiguous too. ${ }^{117}$ It is thus vital to pay equal attention to the ways in which this protest movement reformulates and reconstitutes the concept of modernity itself and comes to terms with it. A potential distinction between modernity and modernism should be made here. ${ }^{118}$ Rigorists are not against modern technical developments, which they use for their own sake. They basically react against the spirit underlying all these modern changes, which relativizes notions of absolute religious truth, emphasizes the secular and supports a permissive, liberal ethos. All this underlines the multifaceted and complex appearances of the phenomenon under investigation.

On the one hand, the fact that Orthodox rigorists accuse the official church of deviations and innovations shows that the concept of tradition and its alleged unaltered preservation in our milieu has to be viewed in another light. Tradition does not represent an immutable and static entity, but is constantly, critically and creatively re-interpreted, re-adjusted and re-constructed by all actors involved. ${ }^{119}$ This takes place even in highly traditional milieus like the Orthodox one, although this is not openly acknowledged by the official hierarchy. In addition, the fact that rigorists support the official church occasionally or are used by it in many instances likewise indicates that their own concept of tradition is not a static one, but rather flexible and adjustable too. After all, they are not mere traditionalists, but rather "radical traditionalists", namely representing a historical process of innovation of their own. ${ }^{120}$ Hence, they make selective use of both the Orthodox tradition and modernity. Ironically enough, their vision to restore an ideal order of the past often ends in an innovative adaptation to the socio-cultural conditions of today. Given the fundamental "heterodoxy" of such protest movements, ${ }^{121}$ this innovation process is not far from the construction of "alternative" and even of "mutating memories" within religious traditions, ${ }^{122}$ as they evolve continuously and are closely related to processes of general socio-cultural change.

116 See Eisenstadt 1999, pp. 82-118.

117 See Makrides 1994, pp. 11-13.

118 See Lawrence 1989, pp. 1-3.

119 See Hervieu-Léger 2000, pp. 83-89.

120 See Riesebrodt 2000, pp. 276-277.

121 See Eisenstadt 1999.

122 See Davie 2000b, pp. 138-155. 


\section{References}

Agadjanian, Alexander: "Neue Formen der östlichen Orthodoxie", in: Transit. Europäische Revue (47) 2015, pp. 90-107.

Agadjanian, Alexander: Turns of Faith, Search for Meaning: Orthodox Christianity and Post-Soviet Experience. Frankfurt am Main 2014.

Aksiuchits, Viktor V.: “Zapadniki i pochvenniki - vchera i segodnia”, in: Vybor: Literaturno-filosofskii al'manakh russkoi khristianskoi kul'tury. Moscow 1990, pp. 163-171.

Alexander, Daniel: "Is Fundamentalism an Integrism?", in: Social Compass (32) 1985, pp. 373-392.

Antes, Peter: "New Approaches to the Study of the New Fundamentalisms", in: Antes, Peter et al. (eds.): New Approaches to the Study of Religion. Vol. 1. Berlin / New York 2002, pp. 437-449.

Antes, Peter: "Fundamentalism: A Western Term with Consequences", in: Method and Theory in the Study of Religions (12) 2000, pp. 260-266.

Bauman, Zygmunt: Postmodernity and its Discontents. Cambridge 1997.

Brady, Dimitri: "Zealots", in: Parry, Ken et al. (eds.): The Blackwell Dictionary of Eastern Christianity. Oxford 2001, pp. 527-528.

Brady, Dimitri / Melling, David J.: "Old Calendarists", in: Parry, Ken et al. (eds.): The Blackwell Dictionary of Eastern Christianity. Oxford 2001, pp. 353-356.

Brüning, Alfons: “'Orthodoxie, Christentum, Demokratie': Orthodoxe Priester als Menschenrechtsaktivisten", in: Makrides, Vasilios N. / Wasmuth, Jennifer / Kube, Stefan (eds.): Christentum und Menschenrechte in Europa. Perspektiven und Debatten in Ost und West. Frankfurt am Main 2016, pp. 103-120.

Buchenau, Klaus: Auf russischen Spuren. Orthodoxe Antiwestler in Serbien, 1850-1945. Wiesbaden 2011a.

Buchenau, Klaus: "Orthodox Values and Modern Necessities", in: Listhaug, Ola / Ramet, Sabrina / Dulić, Dragana (eds.): Civic and Uncivic Values: Serbia in the postMilošević Era. Budapest / New York 2011b, pp. 111-142.

Buchenau, Klaus: Kämpfende Kirchen. Jugoslawiens religiöse Hypothek. Frankfurt am Main 2006.

Casanova, José: "Protestant Fundamentalism - Catholic Traditionalism and Conservatism", in: The Catholic Historical Review (80) 1994, pp. 102-110.

Cavarnos, Constantine: Orthodox Tradition and Modernism. Etna, CA 1992.

Cimino, Richard: "Orthodox Church: Monastic Movement Raising New Controversy in Greek Orthodoxy in America”, in: Religioscope, 24 November 2011, available at: http:// religion.info/english/articles/article_555.shtml\#.VqXqCUZWhXY [24.01.2016].

Clark, Victoria: Why Angels Fall: A Journey through Orthodox Europe from Byzantium to Kosovo. London 2000.

Crego, Paul: “The Georgian Orthodox Church”, in: Leustean, Lucian (ed.): Eastern Christianity and Politics in the Twenty-First Century. London / New York 2014, pp. $140-160$.

Cyprian Agiokyprianites: "The Fundamentalism of the Orthodox Ecumenists", 1997, available at: http://orthodoxinfo.com/ecumenism/fundamentalism.aspx [24.01.2016].

Dalrymple, William: From the Holy Mountain: A Journey in the Shadow of Byzantium. London 1998. 
Davie, Grace: Europe: the Exceptional Case. Parameters of Faith in the Modern World. London 2002.

Davie, Grace: "Prospects for Religion in the Modern World", in: The Ecumenical Review (52) 2000a, pp. 455-464.

Davie, Grace: Religion in Modern Europe: A Memory Mutates. Oxford 2000b.

Demacopoulos, George E.: “Orthodox Fundamentalism”, 29 January 2015, available at: https://blogs.goarch.org/blog///blogs/orthodox-fundamentalism [24.01.2016].

Dépret, Isabelle: Religion, nation, citoyenneté en Grèce: L'Église orthodoxe et le conflit des cartes d'identité. Paris 2012.

Dépret, Isabelle: "Tradition orthodoxe, symboles religieux, mobilisation en Grèce. La loi de 1987 sur le patrimoine ecclésiastique", in: Archives de sciences sociales des religions (149) 2010, pp. 127-145.

Dimanopoulou, Dora: “L'oeuvre de la propagation de la foi et de la morale chrétienne dans la société grecque. L'action de la confrérie Zôè en Grèce, 1907-1938", in: Revue d'histoire ecclésiastique (105) 2010, pp. 121-146.

Dowler, Wayne: Dostoevsky, Grigor'ev and Native Soil Conservatism. Toronto 1983.

Drake, Harold Allen (ed.): Violence in Late Antiquity: Perceptions and Practices. Aldershot 2006.

Eisenstadt, Shmuel N.: Fundamentalism, Sectarianism, and Revolution: The Jacobin Dimension of Modernity. Cambridge 1999.

Fajfer, Łukasz: Modernisierung im orthodox-christlichen Kontext. Der Heilige Berg Athos und die Herausforderungen der Modernisierungsprozesse seit 1988. Frankfurt am Main 2013.

Feldmann, Felix: "Das Altgläubigentum, seine Struktur und sein Zustand heute", in: Zeitschrift für Missionswissenschaft und Religionswissenschaft (79) 1995, pp. 226-239.

Gellner, Ernest: Postmodernism, Reason and Religion. London / New York 1992.

Giannakopoulos, Angelos: Die Theologen-Bruderschaften in Griechenland. Ihr Wirken und ihre Funktion im Hinblick auf die Modernisierung und Säkularisierung der griechischen Gesellschaft. Frankfurt am Main 1999.

Gladigow, Burkhard: "Rigoristische Haltungen und kulturelle Rahmenbedingungen", in: Klosinski, Gunther (ed.): Religion als Chance oder Risiko: Entwicklungshemmende und Entwicklungsfördernde Aspekte religiöser Erziehung. Bern 1993, pp. 54-68.

Hagemeister, Michael: "The Protocols of the Elders of Zion and the Myth of a Jewish Conspiracy in Post-Soviet Russia", in: Brinks, Jan Herman / Rock, Stella / Timms, Edward (eds.): Nationalist Myths and Modern Media: Contested Identities in the Age of Globalization. London / New York 2006, pp. 243-255.

Harwazinski, Assia Maria: "Fundamentalismus/Rigorismus", in: Metzler-Lexikon Religion. Vol. 1. Stuttgart 1999, pp. 427-434.

Hervieu-Léger, Danièle: Religion as a Chain of Memory. New Brunswick, NJ 2000.

Hovorun, Cyril: "Orthodox Fundamentalism: From Religion to Politics", in: The Wheel (4) 2016, pp. 54-60.

Kadotschnikow, Ernest: "Fundamentalismus in Russland", in: Una Sancta (69) 2014, pp. 38-43.

Kalaitzidis, Pantelis: "Orthodoxie und Moderne", in: Transit. Europäische Revue (47) 2015, pp. 76-89. 
Kalaitzidis, Pantelis et al. (eds.): Orthodox Handbook on Ecumenism: Resources for Theological Education. Volos, Greece 2014.

Kalkandjieva, Daniela: “The Bulgarian Orthodox Church”, in: Leustean, Lucian (ed.): Eastern Christianity and Politics in the Twenty-First Century. London / New York 2014, pp. 114-139.

Karpov, Vyacheslav: "Desecularization: A Conceptual Framework", in: Journal of Church and State (52) 2010, pp. 232-270.

Kattan, Assaad Elias: "Heilige Tradition? Tradition und Traditionskritik in der christlichen Orthodoxie am Beispiel der Frage nach dem Frauenamt", in: Grundmann, Regina / Kattan, Assaad Elias (eds.): Jenseits der Tradition? Tradition und Traditionskritik in Judentum, Christentum und Islam, Berlin 2015, pp. 183-194.

Keleher, Serge: "Ecumenism, Eastern Orthodox", in: Parry, Ken et al. (eds.): The Blackwell Dictionary of Eastern Christianity. Oxford 2001, pp. 172-175.

Kelley, Dean: Why Conservative Churches are Growing. New York 1972.

Kishkovsky, Leonid: "Orthodoxy and Ecumenism in Eastern Europe Today", in: Religion in Eastern Europe (20) 2000, pp. 18-29.

Kitromilides, Paschalis M. (ed.): Enlightenment and Religion in the Orthodox World. Oxford 2016.

Kitsikis, Dimitri: The Old Calendarists and the Rise of Religious Conservatism in Greece. Etna, CA 1995.

Kitsikis, Dimitri: "Les anciens calendaristes depuis 1923 et la montée de l'intégrisme en Grèce", in: Cahiers d'études sur la Méditerranée orientale et le monde turco-iranien (17) 1994, pp. 17-51.

Kostiuk, Konstantin N.: "Pravoslavnyi fundamentalizm”, in: Polis (5) 2000, pp. 133-154.

Lawrence, Bruce B.: Defenders of God: The Fundamentalist Revolt against the Modern Age. San Francisco 1989.

Lossky, Nicolas: "Fidelité à la foi et intégrismes", in: Service orthodoxe de presse (167) 1992, pp. 28-32.

Makrides, Vasilios N.: "The Orthodox Church of Greece", in: Leustean, Lucian (ed.): Eastern Christianity and Politics in the Twenty-First Century. London / New York 2014b, pp. 181-209.

Makrides, Vasilios N.: "Orthodoxer Rigorismus und Orthodoxismus: Die Bedeutung des wortgetreuen Verständnisses von Rechtgläubigkeit”, in: Una Sancta (69) 2014a, pp. 44-50.

Makrides, Vasilios N.: "Orthodox Christianity, Modernity and Postmodernity: Overview, Analysis and Assessment”, in: Religion, State \& Society (40) 2012, pp. 248-285.

Makrides, Vasilios N.: "Greek Orthodox Compensatory Strategies Towards Anglicans and the West at the Beginning of the Eighteenth Century", in: Doll, Peter M. (ed.): Anglicanism and Orthodoxy 300 Years after the 'Greek College' in Oxford. Oxford 2006, pp. 249-287.

Makrides, Vasilios N.: "Between Normality and Tension: Assessing Church-State Relations in Greece in the Light of the Identity (Cards) Crisis", in: Makrides, Vasilios N. (ed.): Religion, Staat und Konfliktkonstellationen im orthodoxen Ost- und Südosteuropa. Vergleichende Perspektiven. Frankfurt am Main 2005, pp. 137-178.

Makrides, Vasilios N.: "L' 'autre' orthodoxie: courants du rigorisme orthodoxe grec", in: Social Compass (51) 2004, pp. 511-521. 
Makrides, Vasilios N.: "Nuove prospettive dell'omogeneità religiosa: la chiesa e la fede ortodossa in Grecia alle soglie del terzo millennio", in: Pacini, Andrea (ed.): L'Ortodossia nella nuova Europa. Dinamiche storiche e prospettive. Torino 2003, pp. 185 236.

Makrides, Vasilios N.: "Religion et société dans l'orthodoxie grecque / Quelques conséquences socioculturelles du concept d'orthodoxie", in: Annuaire de l'École Pratique des Hautes Études. Section des sciences religieuses (110) 2001-2002, pp. 371-375.

Makrides, Vasilios N.: "Fundamentalism, Orthodox", in: Speake, Graham (ed.): Encyclopedia of Greece and the Hellenic Tradition. Vol. 1. London / Chicago 2000, pp. 632633.

Makrides, Vasilios N.: Die religiöse Kritik am kopernikanischen Weltbild in Griechenland zwischen 1794 und 1821. Aspekte griechisch-orthodoxer Apologetik angesichts naturwissenschaftlicher Fortschritte. Frankfurt am Main 1995.

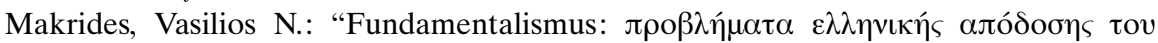

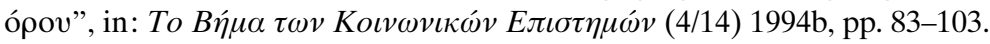

Makrides, Vasilios N.: "Fundamentalismus aus religionswissenschaftlicher Sicht", in: Dialog der Religionen (4) 1994a, pp. 2-25.

Makrides, Vasilios N.: "Aspects of Greek Orthodox Fundamentalism", in: Orthodoxes Forum (5) 1991, pp. 49-72.

Makrides, Vasilios N. / Uffelmann, Dirk: "Studying Eastern Orthodox Anti-Westernism: The Need for a Comparative Research Agenda", in: Sutton, Jonathan / Van den Bercken, Wil (eds.): Orthodox Christianity and Contemporary Europe. Leuven 2003, pp. 87-120.

Makrides, Vasilios N. / Wasmuth, Jennifer / Kube, Stefan (eds.): Christentum und Menschenrechte in Europa. Perspektiven und Debatten in Ost und West. Frankfurt am Main 2016.

Metallinos, Georg: "Das Problem der deutschen Einflüsse auf die griechische akademische Theologie in der Gründungsphase der Athener Universität", in: Orthodoxes Forum (3) 1989, pp. 83-91.

Mitrofanova, Anastasia V.: "Orthodox Fundamentalism: Intersection of Modernity, Postmodernity, and Tradition”, in: Tolstoya, Katya (ed.): Orthodox Paradoxes: Heterogeneities and Complexities in Contemporary Russian Orthodoxy. Leiden / Boston 2014, pp. 93-105.

Mitrofanova, Anastasia V.: Politizatsiia "pravoslavnogo mira”. Moscow 2004.

Mitrokhin, Nikolai: Russkaia pravoslavnaia tserkov': Sovremennoe sostoianie i aktualn'ye problemy. Moscow 2004.

Moga, Ioan: "Das orthodoxe Mönchtum und die Ökumene - Eine unmögliche Freundschaft? Fallbeispiel Rumänien", in: Ostkirchliche Studien (59) 2010, pp. 70-98.

Morris, John W.: Orthodox Fundamentalists: A Critical View. Minneapolis, MN 1998.

Papandreou, Damaskinos: Dialog als Leitmotiv. Die Orthodoxie an der Schwelle zum dritten Jahrtausend. Athen 2000.

Papkova, Irina: The Orthodox Church and Russian Politics. New York 2011.

Platonov, Andrei: "O sobytiiakh v Ekaterinburge", in: Nezavisimaia gazeta, 12 June 1998.

Pelikan, Jaroslav: "Fundamentalism and/or Orthodoxy? Toward an Understanding of the Fundamentalist Phenomenon", in: Cohen, Norman J. (ed.): The Fundamentalist 
Phenomenon: A View from Within; A Response from Without. Grand Rapids, MI 1990, pp. 3-21.

Plekon, Michael: "Relativism and Fundamentalism: An Eastern Church Perspective from the 'Paris School' and Living Tradition", in: Berger, Peter L. (ed.): Between Relativism and Fundamentalism: Religious Resources for a Middle Position. Grand Rapids, MI 2010, pp. 180-209.

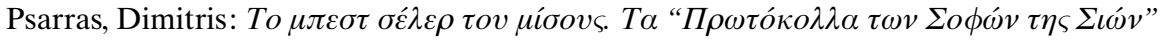
$\sigma \tau \eta v E \lambda \lambda \alpha ́ \delta \alpha, 1920-2013$. Athens 2013.

Ramet, Sabrina P.: "The way we were - and should be again? European Orthodox Churches and the 'Idyllic Past'", in: Byrnes, Timothy A. / Katzenstein, Peter J. (eds.): Religion in an Expanding Europe. Cambridge 2006, pp. 148-175.

Riesebrodt, Martin: "Fundamentalism and the Resurgence of Religion", in: Numen (47) 2000, pp. 266-287.

Riesebrodt, Martin: Fundamentalismus als patriarchalische Protestbewegung. Amerikanische Protestanten (1910-28) und iranische Schiiten (1960-79) im Vergleich. Tübingen 1990.

Robbins, Thomas: "Religious Mass Suicide before Jonestown: The Russian Old Believers", in: Sociological Analysis (47) 1986, pp. 1-20.

Rock, Stella: "Fraternal Strife: Nationalist Fundamentalists in the Contemporary Russian Orthodox Brotherhood Movement", in: Sutton, Jonathan / Van den Bercken, Wil (eds.): Orthodox Christianity and Contemporary Europe. Leuven 2003, pp. 319-342.

Rock, Stella: "Militant Piety: Fundamentalist Tendencies in the Russian Orthodox Brotherhoods Movements", in: Religion in Eastern Europe (12) 2002, pp. 1-17.

Roudometof, Victor: "Orthodox Christianity as a Transnational Religion: Theoretical, Historical and Comparative Considerations", Religion, State \& Society (43) 2015, pp. 211-227.

Rousselet, Kathy: "Le mouvement des fraternités orthodoxes en Russie", in: Revue d'études comparatives Est-Ouest (3-4) 1993, pp. 121-138.

Roy, Olivier: Holy Ignorance: When Religion and Culture part Ways. New York 2010.

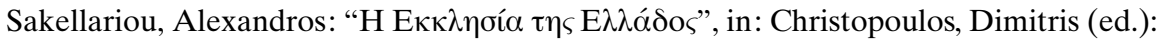

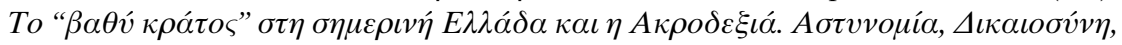

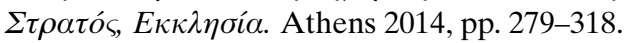

Schaeffer, Frank: Dancing Alone: The Quest for Orthodox Faith in the Age of False Religion. Salisbury, MA 2002.

Schaeffer, Frank: Letters to Father Aristotle: A Journey through Contemporary American Orthodoxy. Salisbury, MA 1995.

Scheffel, David Z.: In the Shadow of Antichrist: The Old Believers of Alberta. Peterborough, Ontario 1991.

Selbach, Christopher: "The Orthodox Church in Post-Communist Russia and her Perception of the West: A Search for a Self in the Face of an Other", in: Zeitschrift für Religionswissenschaft (10) 2002, pp. 131-173.

Seraïdari, Katerina: "Le Pape à Athènes: limites floues entre politique et religion", 2002, available at: http://www.afebalk.org.rencontres2002/textes/K.Seraidari.pdf [24.01.2016].

Shenfield, Stephen D.: Russian Fascism: Traditions, Tendencies, Movements. New York 2001. 
Shnirelman, Victor: "Russland und die Apokalypse. Zwischen Eschatologie, Esoterik und Verschwörungsglaube”, in: Transit. Europäische Revue (47) 2015, pp. 131-149.

Slater, Wendy: "A Modern-Day Saint? Metropolitan Ioann and the Postsoviet Russian Orthodox Church", in: Religion, State \& Society (28) 2000, pp. 313-325.

Stark, Rodney: One True God: Historical Consequences of Monotheism. Princeton, NJ 2001.

Stewart, Charles: "Who Owns the Rotonda? Church vs. State in Greece", Anthropology Today (14/5) 1998, pp. 3-9.

Stieger, Olga: "Ultraorthodoxe in Russland", in: Religion und Gesellschaft in Ost und West (39/10) 2011, pp. 22-23.

Stoeckl, Kristina: The Russian Orthodox Church and Human Rights. London 2014.

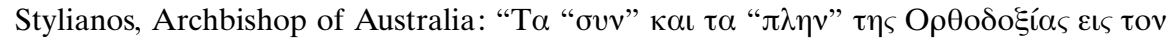

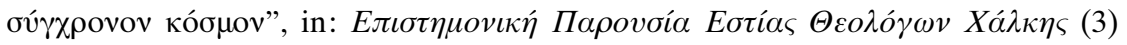
1994, pp. 573-602.

Turcescu, Lucian / Stan, Lavinia: "The Romanian Orthodox Church", in: Leustean, Lucian (ed.): Eastern Christianity and Politics in the Twenty-First Century. London / New York 2014, pp. 94-113.

Verkhovsky, Alexander: "Holy Russia versus the Fallen World: Conservative Orthodox Mythologies in Contemporary Russia", in: Brinks, Jan Herman / Rock, Stella / Timms, Edward (eds.): Nationalist Myths and Modern Media: Contested Identities in the Age of Globalization. London / New York 2006, pp. 229-242.

Verkhovsky, Alexander: "The Role of the Russian Orthodox Church in Nationalist, Xenophobic and Anti-Western Tendencies in Russia Today: Not Nationalism, but Fundamentalism", in: Religion, State \& Society (30) 2002, pp. 333-345.

Verkhovskii, Aleksandr: "Ksenofobiia i religiia v Rossii", in: Dia-Logos: Religiia i Obshchestvo, Moscow 1998-99, pp. 97-136.

Vladimir (Sokolov): Mladostarchestvo i pravoslavnaia traditsiia. Moscow 2005.

Uliakhin, Valentin N.: "Fundamentalizm v pravoslavii: Teoriia i praktika", in: Levin, Zemlan I. (ed.): Fundamentalizm. Stat'i. Moscow 2003, pp. 129-164.

Walters, Philip: “Turning Outwards or Turning Inwards? The Russian Orthodox Church Challenged by Fundamentalism", in: Nationalities Papers (35) 2007, pp. 853-879.

Ware, Kallistos: "Old Calendarists", in: Clogg, Richard (ed.) Minorities in Greece. Aspects of a Plural Society. London 2002, pp. 1-23.

Yannaras, Christos: "Die Herausforderung des orthodoxen Traditionalismus", in: Concilium (28) 1992, pp. 249-254.

Yannaras, Christos: "Orient-Occident. La signification profonde du schisme (interview)", in: Service orthodoxe de presse (150) 1990, pp. 29-35. 